\title{
SARS-CoV-2 and pathological matrix remodeling mediators
}

\author{
Imen Guizani ${ }^{1,2} \cdot$ Nesrine Fourti $^{1,2} \cdot$ Wiem Zidi $^{1} \cdot$ Moncef Feki $^{1} \cdot$ Monia Allal-Elasmi ${ }^{1}$ (]
}

Received: 7 April 2021 / Revised: 4 July 2021 / Accepted: 7 July 2021 / Published online: 20 July 2021

(c) The Author(s), under exclusive licence to Springer Nature Switzerland AG 2021

\begin{abstract}
Background Recognizing only sharp elevation in a short period of time, the COVID-19 SARS-CoV-2 propagation is more and more marked in the whole world. Induced inflammation afterwards infection engenders a high infiltration of immune cells and cytokines that triggers matrix metalloproteinases (MMPs) activation. These endopeptidases are mediators of the lung extracellular matrix (ECM), a basic element for alveoli structure and gas exchange.

Methods When immune cells, MMPs, secreted cytokines and several other mediators are gathered a pathological matrix remodeling occurs. This phenomenon tends to tissue destruction in the first place and a pulmonary hypertrophy and fibrosis in the second place.

Findings After pathological matrix remodeling establishment, pathological diseases take place even after infection state. Since post COVID-19 pulmonary fibrosis is an emerging complication of the disease, there is an urge to better understand and characterize the implication of ECM remodeling during SARS-CoV-2 infection.

Conclusion Targeting MMPs and their inhibitors could be a probable solution for occurred events since there are many cured patients that remain with severe sequels even after the end of infection.
\end{abstract}

Keywords MMPs · Matrix remodeling $\cdot$ Immune cells $\cdot$ Cytokine $\cdot$ SARS-CoV-2 $\cdot$ Therapeutic target

\section{Introduction}

The emerging pandemic caused by the severe acute respiratory syndrome coronavirus-2 (SARS-CoV-2) brought a state of alert around the world. SARS-CoV-2 belongs to the Betacoronavirus family which includes two other viruses known for other pandemic diseases: the Middle East Respiratory syndrome coronavirus (MERS-CoV) and severe acute respiratory syndrome coronavirus (SARS$\mathrm{CoV}$ ), respectively [1-4]. SARS-CoV-2 shares $79.6 \%$ of its genome with SARS-CoV-1 and $96 \%$ with the bat coronavirus (RaTG13) which make it most likely deriving from the later $[1,5]$. SARS-CoV-2 shares important sequence homology with SARS-CoV but also a common entry receptor

Responsible Editor: John Di Battista.

Monia Allal-Elasmi

monia_elasmi@yahoo.fr

1 LR99ES11, Laboratory of Biochemistry, Department of Biochemistry, Faculty of Medicine, La Rabta Hospital, University of Tunis El Manar, Jebbari, 1007 Tunis, Tunisia

2 Faculty of Mathematics, Physics and Natural Sciences, University of Tunis El Manar, Tunis, Tunisia angiotensin-converting enzyme 2 (ACE2). For such reason, several authors have suggested that their biological properties could be similar and understanding host response to SARS-CoV-1 may help us understanding SARS-CoV-2 implication at various levels $[4,6,7]$.

Latest models suggest that following SARS-CoV-2 invasion in type II pneumocytes (via ACE2) leads to a rapid virus replication as well as concomitant intense secretion of pro-inflammatory cytokines, chemokines, and other proteases are mainly secreted by the innate immune cells' response [8]. Subsequent excess inflammation, especially in the lung further (the so-called "cytokine storm") leads to acute respiratory distress syndrome (ARDS), pulmonary edema and endothelial damage [1].

On a molecular scale, when all of these inflammatory mediators are gathered, there is an increase of matrix metalloprotease (MMPs) secretion in site of the inflammation. This increase leads to a pathological remodeling of lung's extracellular matrix (ECM) [1, 8-10]. MMPs are members of the proteolytic zinc-dependent family. There are 24 recognized members until today and they are included in several vital mechanisms and pathways including majorly wound healing, ECM degradation, angiogenesis, proliferation and 
signaling pathways $[11,12]$. While present in low quantity at homeostasis, their increased secretion and imbalance have been widely studied in various lung pathologies in chronic and acute nature.

Since they are involved in different pathways and physiological phenomena, disequilibrium in their levels opens the door to pathological situations translated by serious diseases like cancer, cardiovascular diseases, neurodegenerative diseases and chronic inflammation which explains why they drew so much attention lately. Even though the fact that they are capable of modulating cellular behavior in a nonspecific way, they could be considered as therapeutic targets [13]. Secreted MMPs enhance pro-inflammatory cytokines, bioactive chemokines and oxygen reactive. They are even included in infection propagation in the organism through their members with transmembrane domain like ADAM17 which leads us to ask about their real implication even with fluctuated levels [14-16]. In fact, metallopeptidases are probably included in immune cells infiltration since they are mediators of ECM and basement membrane breakdown that surrounds the parenchymal ECM and blood vessels.

The combination of ARDS and hyper-inflammation has the potential of driving pulmonary fibrosis. Since postCOVID-19 pulmonary fibrosis is an emerging complication of the disease, there is an urge to better understand and characterize the implication of ECM remodeling during SARS-CoV-2 infection. This review focuses on current and emerging evidence regarding the pathophysiological role of metallo-endopeptidases, particularly MMPs, in determining the remodeling process in lung tissue damage during SARSCoV-2 infection.

\section{The SARS-COV-2/ACE2 pathway to infection}

Through genome sequencing and by homology modeling, the angiotensin-converting enzyme 2 (ACE2) has been reported to be the target for SARS-CoV-2 [3]. Specific binding between spike (S) glycoprotein of coronavirus and the ACE2 receptor followed by $S$ cleavage by serine protease 2 (TMPRSS2) allows for virus entry to cell $[1,4,17]$. Several studies of gene expression datasets have reported that ACE2 more than TMPRSS2 may be the limiting factor for viral entry at the initial stage [3]. Moreover, the study reported a high expression of ACE2 in nasal secretory and ciliated cells as well as type II alveolar epithelial cells (AEC). At homeostasis, quiescent types II AEC are the major source of ACE2 within the lung. During lung fibrosis, those cells actively proliferate and downregulate the expression of this enzyme. ACE2 expression is severely downregulated in the context of pneumocyte proliferation and lung fibrosis [18].

The viral spike protein $(\sim 1300$ amino acid residues $)$ is formed by two functionally subunits: $\mathrm{S} 1$ contains the receptor-binding domain (RBD) attached to $\mathrm{S} 2$, which contains the post-fusion core $[19,20]$. This process is crucial for the virus cell entry resulting in shedding $\mathrm{S} 1$ subunit from the viral surface [4]. The S-protein undergoes conformational rearrangements allowing the $\mathrm{S} 2$ subunit a postfusion conformation [19, 21, 22]. Besides the proteolytic cleavage of SARS-CoV-2 $\mathrm{S}$ by TMPRSS2, a smaller rate of endosomal cysteine proteases cathepsin $\mathrm{B}(\mathrm{CatB})$ and cathepsin $\mathrm{L}$ (CatL) has been reported to assist in priming and entry process [4,23] (Fig. 1A). A distinctive feature of the SARS-CoV-2 S-protein is the Furin cleavage site acquirement, polybasic cleavage site (RRAR) at S1-S2 junction which is cleaved efficiently by furin enzyme [24]. The S1/S2 junction and S2' are the two cleavage sites in viral S-protein, allowing the activation and priming process through host cell enzymes trypsin, cathepsins, furin and TMPRSS2 [4, 25]. After this bond, the virus membrane and the host cell membrane fuse together through their ligand-receptor link and then the virus enters the host cell [26]. The angiotensinconverting enzyme 2 (ACE2) is a homolog of the ACE.

ACE2 is a widely expressed enzyme with pleiotropic roles which is part of the Renin-Angiotensin System (RAS). ACE2 is the homologous of ACE and shares a high affinity to the angiotensin II (ANG-II) [6, 27, 28, 31, 32]. There are three discovered receptors for the ANG-II until today. Among these receptors, the angiotensin I (AT1R) leads to vasoconstriction, induces inflammatory responses and enhances matrix remodeling, whereas the AT2R reverses the ANG-II effects [28, 29], while ACE-ANG-II-AT1R axis activation has been proven to causes deleterious effects, such as vasoconstriction, inflammation, and fibrosis [28-30]. The ACE2-ANG I-7-Mas axis appears to counter-regulate the ACE-ANG-II-AT1 negative effects anti-thrombotic, antiproliferative, anti-fibrotic, and anti-inflammatory properties [31, 32].

ACE2 acts like a transmembrane enzyme with an extracellular domain and presents a target site for the SARS-CoV-2 to mediate its actions [33]. When the SARS-CoV-2 enters into the organism, it binds directly through its glycoprotein spike existent on its viral membrane to the host cell receptors [4, 34]. The recently made study by Zhou and its collaborators demonstrated that SARS-CoV-2 entry to the host cell is mainly insured by the ACE2 cell receptor since cells that do not express this receptor are not infected [1]. However, on T lymphocytes in vitro, SARS-CoV-2 is capable of using other cellular receptors of S-protein to infect cells that do not express the ACE2 receptor [35]. It is plausible that interaction of ACE2 with SARS-COV-2 may induce its downregulation and thereby enhance the ACE-AngII-AT1 axis leading to vasoconstriction, pro-inflammatory and oxidative stress. In a recent study, Liu et al. reported higher serum Ang II levels in patients with higher viral load which further supports this hypothesis [36]. Afterwards, the viral RNA is injected into 


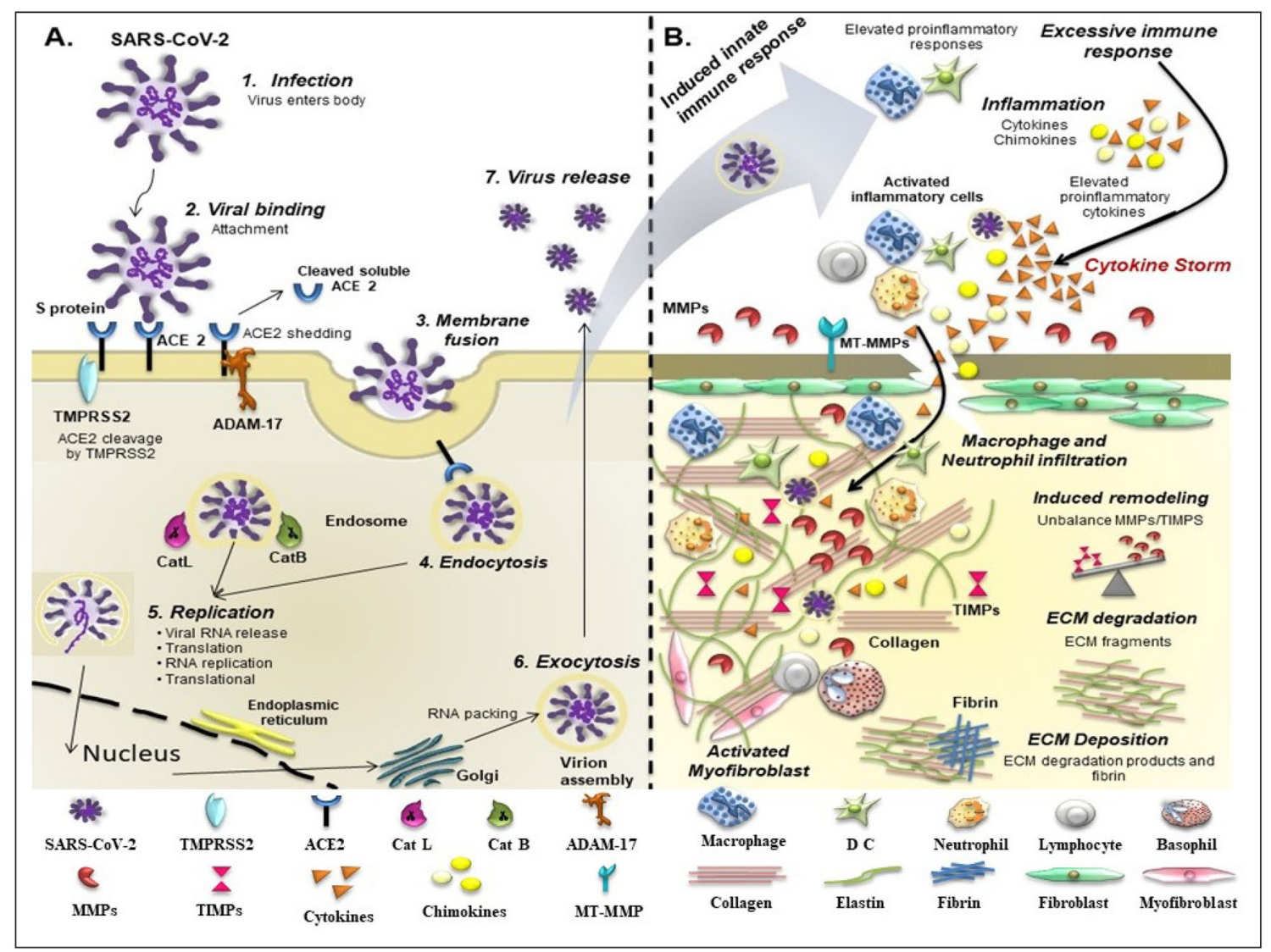

Fig. 1 Induced pathological matrix remodeling after SARS-CoV-2 infection. A Cell entry mechanism of SARS-CoV-2 summary: the initial step of SARS-CoV-2 infection involves a specific binding of $S$-protein to host cell entry receptors, angiotensin-converting enzyme 2 (ACE2). Gathered together and with the host cell surface serine protease TMPRSS2, the entry process is activated. Following the endocytosis, cathepsins are released. These proteases modify once again the S-protein and promote the release of viral RNA into the cytoplasm. B SARS-CoV-2 Physio-pathological implications: when virus propagation occurs, a massive destruction of tissues takes place. An epithelial damage is the initial hallmark of SARS-CoV-2 infection. A specific immune response is induced to eliminate the virus and initiate the inflammatory response. The immune cells, in particular, macrophages identify the virus and release pro-inflammatory mediators (cytokines, chemokines, growth factors...). Cytokines activate more immune cells, which in turn produce more cytokines creating an uncontrolled cycle of inflammatory response "cytokine storm". Activated immune and non-immune cells produce MMPs which lead to ECM breakdown disruption and this unresolved infection gives rise to damages. These damages do happen during the cytokine storm which includes the unbalance of the MMPs/TIMPs ratio, the increase deposition of ECM fragments, and the massive formation and deposition of fibrin. ACE2 angiotensin-converting enzyme 2, ADAM-17 ADAM metalloprotease domain 17, Cat $L$ cathepsin L, Cat $B$ cathepsin B, TMPRSS2 transmembrane protease serine 2, DC dendritic cell, $M M P s$ matrix metalloproteinases, $M T-M M P s$ membrane-type matrix metalloproteinases, TIMPs tissue inhibitors of matrix metalloproteinases the cell cytoplasm, and its open reading fragment (ORF) is directly translated into proteins. These proteins are cleaved by their viral proteases generating their RNA-dependent RNA polymerase ( $\mathrm{RdRp}$ ) necessary for RNA replication. Genomic RNA is thereby replicated by its specific RdRp in presence of structural proteins (Spike, envelop protein, Membran Protein and Nucleocapsid) and is translated by the Golgi complex and the endoplasmic reticulum's host cell. The replicated RNA and structural proteins are gathered to produce new viral particles and are secreted by exocytosis [6, 7] (Fig. 1A). 


\section{From lung infection to extracellular matrix remodeling}

A very thin alveolocapillary membrane allows oxygen and $\mathrm{CO}_{2}$ to diffuse through the cells. During the first level of infection, the viral spike binds to the ACE2 receptor on the host cell surface. This bond leads to the incapacity of regulating ANG-II which provokes a sudden increase of the inflammatory response. This increase induces the activation of a large scale of cells including cytokines, and MMPs [37-39]. The sudden activation of these endopeptidases induces matrix disequilibrium and this phenomenon leads in turn to the collapse of matrix. On the one hand, MMPs will be highly activated since the inflammatory response implies a storm of cytokines. On the other hand, the ANG-II increase leads to MMPs increase. In a study made on tuberculosis pleural effusion, ACE2 and MMP-9 do correlate negatively, more precisely when ACE2 receptors are taken by the virus, an increase in ANG-II arises leading to the MMP-9 activation [40]. ACE2 is a pleotrope receptor; it counterattacks the ANG-II and leads to vascular wall hypertrophy. This receptor captures the ANG-II and converts it to reverse its effect. During the infection, the receptor is linked to the virus for its profit. In response to the infection, a lung injury and organ failure occur. As SARS-CoV-2 emerges in human body, a huge storm of inflammatory cytokines comes by. Tissue damage is specific to the virus and then it also appears in multiple other damages [39]. Induced proteolysis by secreted MMPs through the activated inflammatory cells and cytokines has been included in a fatal process. MMPs' proteolytic action seems to be involved in COV-2 pathogenesis, similar to several diseases that are related to tissue damage (Fig. 1B).

\section{The role and fate of the pulmonary extracellular matrix}

The lung has a very specific ECM. At healthy state, the ECM forms a thin membrane which allows for passive diffusion of passive diffusion of gas through alveolar-interstitial membrane. The alveoli air exchange structure is composed mainly of an air barrier. This barrier comprises a capillary and an alveolar epithelium, an extracellular matrix and alveolar mediators including fibroblasts and macrophages [41]. To facilitate ventilation, this structure maintains in the same time gas exchange and ECM mechanical properties. ECM is also implicated in inter-cell signaling, in cell function, proliferation and shape. It is highly sensitive to growth factors, such as TGF-Beta. Type I alveolar cell ensures the gas exchange through basal lamina. As for the rest of the solute and liquid exchange, it is ensured by ECM components [41,
42]. During fibrosis, the ECM expands which limits gas diffusion. Also, a pathological fibro-proliferation of the alveoli ECM arises [43, 44]. Lung ECM is a complex and dynamic tissue that has a tremendous role in maintaining a normal connective structure. In lungs, ECM is mainly composed of a thin basement membrane and an interstitial tissue that forms the lung's parenchyma [45] and provides structural support for gas exchange by developing a branched architecture [46]. Also, ECM is widely implicated in signaling pathways through its specific mediators, in cell function and shape, in proliferation mechanisms and in responding to growth factors [47-49]. Lung ECM major components are collagen and elastin fiber that are overlapping with glycosaminoglycans, proteoglycans, fibronectin fibrils and sequestered water [46] (Fig. 2A). Resident fibroblasts are abundant and are mainly in charge of ECM production. Furthermore, laminin, heparan sulfate, hyaluronate, nidogen/entactin, and matricellular proteins like thrombospondin, tenascin $\mathrm{C}$, and tenascin-X have been also identified in alveolar tissues. With all of this wealth in the matrix structure, collagen is the most abundant protein in lung tissue. In lung parenchyma, collagen types I and III predominate the alveolar membrane $[46,50]$. After SARS-CoV-2 infiltration in lungs, an acute severe inflammatory response occurs. Following viral entry into host cell, RNA is recognized by the cytoplasmic pattern recognition receptor (PRR) leading to transcription factors activation through the toll interleukin receptor 1 containing interferon beta (TRIF). This activation leads to interferon- $\gamma$ (IFN- $\gamma$ ) secretion [51, 52]. However, an insufficient level of IFN-1 for infection control enhances viral replication. In other patients, IFN- $\gamma$ serum level is more important. This fact is the reason behind the cytokine storm particularly myeloid cytokine (IFN- $\gamma$; GM-CSF). Their activation attracts immune cells (monocytes, lymphocytes, peripheral blood mononuclear cells) in the infection site [53].

IFN- $\gamma$ production during early infection phase is the immune defense key against the virus emerge [51] and a delay in their release at early stages of COVID-19 makes it harder for the antiviral response. This release enhances cytokine secretion and through the chemiotactic phenomena, more inflammatory cells are attracted. Afterwards, an extreme infiltration in lung tissue arises [54, 55]. The emerging concept elaborated by McGonagle and his collaborators discussed the probability that the induced cytokine storm during SARS-CoV-2 infection result from the immune system failure to eradicate the virus. They divided the storm in two phases [53]. At a first level, there is a loss of the first anti-viral line defense. In fact, the Toll receptor like-3 (TLR3 ) is capable of recognizing the double-stranded viral RNA. This fact leads to TRIF activation which in turn activates Interferon Regulated Factor 3 (IRF-3) and Nuclear Factorkappa B (NF- $\mathrm{kB})$ to enhance IFN- $\gamma$ and Tumor Nescrosis Factor- $\beta$ (TNF- $\beta$ ) production. Theses pro-inflammatory 


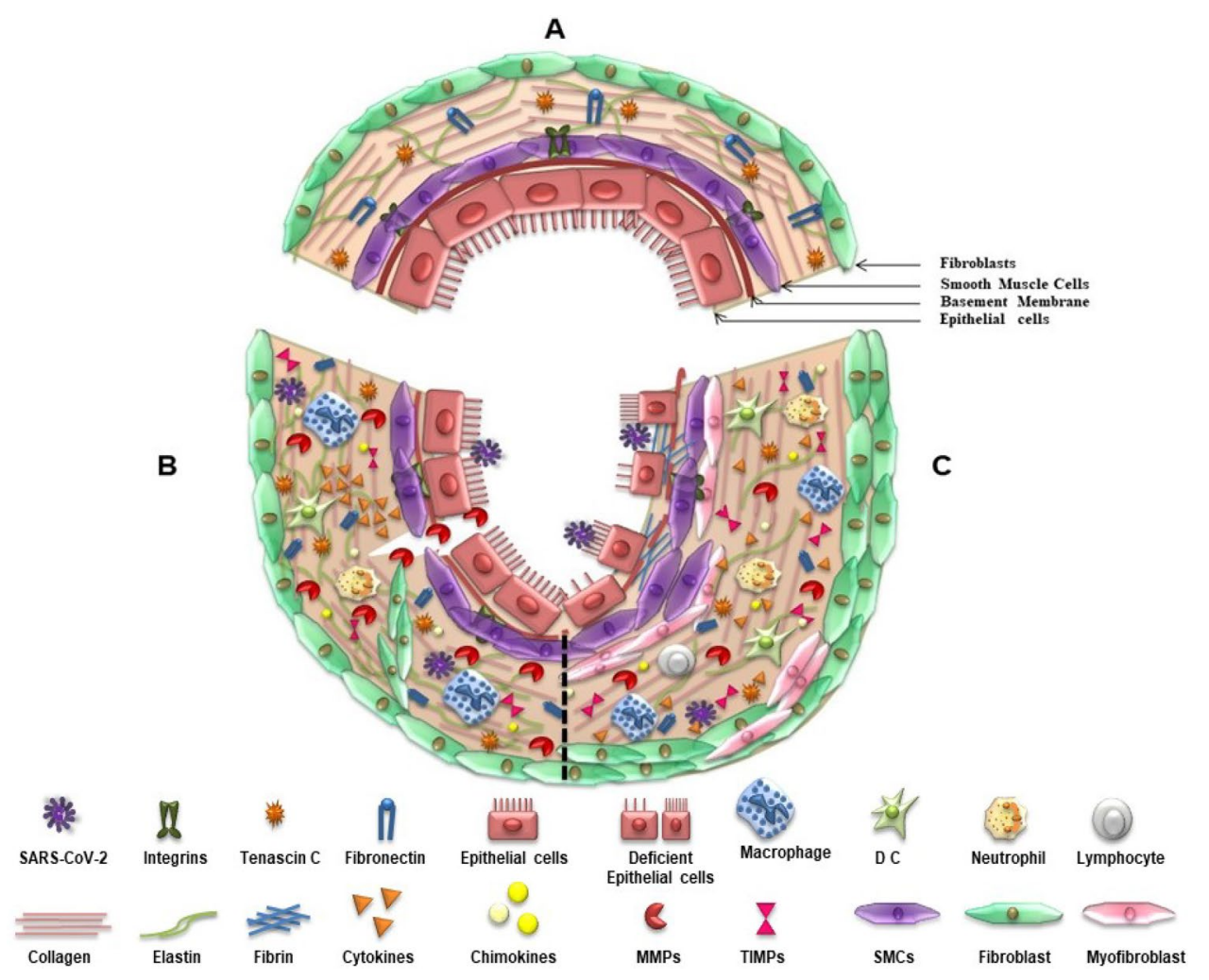

Fig. 2 ECM lung evolution from healthy to a pathological matrix. A Healthy lung matrix structure is preserved by the presence of fibroblasts, collagen, elastin and anchored fibronectin to basal membrane. B ECM breakdown after virus infiltration and MMP overexpression (from day 1 to 5 of infection): collagen fibers destruction through secreted MMPs by inflammatory cells. This destruction leads to basement membrane disruption. C ECM lungs fibrosis and hypertrophy (from day 5 of infection and more): after increased degradation, a

cytokines are considered to be in the first line of defense and the loss of this is due to the viral charge and hypo-secretion of IFN-1 [51, 53, 55].

As a consequence, a second storm is activated, that is more tissue aggressive than the first one to cover up for the first target failure during the first response [55, 56]. During this phase, myeloid IFN- $\gamma$ pathway and derived cytokine that includes TNF, GM-CSF and IL-1 are overexpressed in blood, rendering it in a hyper-cytokinaemic mode. The cytokine shock is explained until this day as the ultimate uncontrolled systemic inflammation that is triggered by cytokines hypersecretion after infection which leads to organ failure and that might cause death [57].

When all of these factors are gathered all together, a tissue destruction could occur. In fact, following the viral infection by the SARS-CoV-2 virus, an ECM breakdown takes place which leads to the aggravation of lung state and provokes lung pathologies progression (Fig. 2B). The immune cells influx into lungs does protect the host cell against excessive immune responses including both innate and adaptive. remodeling takes place to respond to lung injuries. However, ECM mediators' imbalance and SMC migration lead to increased collagens and matrix degradation products deposition that are presumed in a thickened matrix. SARS-CoV-2 severe acute respiratory syndrome coronavirus-2, MMP matrix metalloproteinase, TIMP tissue inhibitor of matrix metalloproteinase, ECM extracellular matrix, SMC smooth muscle cells, $D C$ dendritic cells

This fact enhances chronic inflammation which in turn destroys the lung's parenchyma [58, 59]. T lymphocytes, the adaptive immune cells, are headed to ECM lung's components. These mediators are capable of inducing abnormal immune responses that enhance lung destruction. During innate and adaptive immunity activation, triggered immune cells induced innate inflammation in the lung. Excessive immune response starts a sequence of signals that overlaps lung stroma which are exposed to antigen-presenting cells (APCs) towards lymphocytes for generating the major histocompatibility complex (MHC) [60]. To activate APCs, specific signals must be secreted. ECM breakdown and degradation products may engender new antigens that are recognized by immune cells resident in lung [60-63]. This injury engenders an alveolar basement membrane disruption and the accumulation of matrix degradation products that are rich in fibrin [64]. ECM bioactive fragments are in turn mediators of inflammation since collagen degradation is implicated in neutrophil migration. Collagen I Proteolytic 
fragment is capable of acting like chemokines and attracts immune cells by binding to their receptors $[65,66]$.

Lung ECM major components were absent in infected lungs with SARS-CoV-2 which leads to a severe mechanical damage presumed in COVID-19 characteristics [67]. In their recent proteomic analysis of lung tissues from deceased patients suffering from severe forms of COVID-19, Leng et al. reported several major components of ECM homeostasis to be downregulated. For example, the ECM protein annexin A2 (ANXA2), which regulates surfactant secretion by type II pneumocyte was significantly downregulated [67]. Surfactant dysregulation plays a major role in ARDS pathophysiology [68]. Thereby, maintaining a normal state of surfactants could improve the prognosis of severe patients suffering from COVID-19 [69]. ECM fate is related to a balance between degradation and secretion of matrix components. It is related to myofibroblasts after injury for a fibrotic repair since interactions between fibroblasts and ECM components enhance matrix production and stimulate signaling pathways [35, 70] (Fig. 2C).

\section{Mediators of lung ECM breakdown}

ECM breakdown is mediated by MMPs that are capable of degrading ECM components and are characterized by the presence of the metallic ion $\mathrm{Zn}^{2+}$ that confers the catalytic activity [11]. There are 28 MMPs discovered in vertebrates until this day [71], 24 of which are expressed in human tissues; they are divided according to their structure and their substrate specificity [72]. Their basic structure is limited to a pre-domain which represents a signal peptide for secretion and is eliminated after its secretion. The pre-domain is followed by a pro-domain that ensures the enzyme latent form and is mainly formed by a peptide sequence containing a cysteine residue which interacts with the catalytic site. This site has a zinc atom maintained by three histidine residues in a tri-dimensional structure $[11,73]$. Thereby comes the catalytic domain which comprises a linked site to zinc with a highly conserved sequence $H E X X H X X G X X H$ [74]. Pro-domain cleavage releases the zinc ion and activates the catalytic site that can bind afterwards to its substrate through $\mathrm{H}_{2} \mathrm{O}$ penetration.

According to their specificity and primary structure, the first group is composed of collagenases (MMP-1, MMP-8 and MMP-13). The second group englobes the gelatinases (MMP-2 and MMP-9) and the third the Stromelysines (MMP-3, 10 and 11). MMPs that contain a membranetype (MT-MMPs) are members of the fourth group that can be subdivided into two subgroups, type I transmembrane proteins (MMP-14, 15, 16, and 24) and glycosylphosphatidylinositol (GPI) anchored proteins (MMP-17 and -25) [75]. The enzyme structure is also formed by a hinge region and a hemopexin domain that interferes into MMPs recognition of their substrate except for MMP-7, 23 and 26 that do not possess the hemopexin domain $[13,73,76]$. Secreted MMPs at site of lung inflammation are capable of modulating inflammatory mechanisms whether by affecting chemokine activity, disposal or by targeting proteins that are in a direct association with their activity [77-79].

As for adamalysins, they are in the same time metalloproteinase and disinegrin and are characterized by a thrombospondin motif [80]. Their structure is mainly composed of a pro-domain, a zinc-binding domain, a disintegrin domain that confers interaction to the ADAM, a cysteine-rich domain for ECM interaction, an epidermal growth factor domain and a cytoplasmic tail [81, 82]. Also, the fact that ACE2 contains a HEXXH zinc-binding motif makes it a metalloproteinase [33]. MMPs are capable of modulating inflammatory mechanisms whether by affecting chemokine activity, disposal or by targeting proteins that are in a direct association with their activity $[77,78]$.

Secreted MMPs by macrophages like MMP-12 and MMP-28 are included in the pro-inflammatory process by enhancing macrophage infiltration in lungs [83]. Another mediator of immune cells is the matrilysin (MMP-7). This MMP does promote neutrophil infiltration via the epithelial barrier by degrading the transmembrane proteoglycan coordinated to the $\mathrm{KC}$. The $\mathrm{KC}$ is a murine chemokine $(\mathrm{CXC})$ that is implicated in attracting inflammatory cells [77]. The MMP-8 nearly shares this characteristic from the MMP-7 and possesses a chemiotactic effect on neutrophils but in a more active structure. Under the influence of chemokines, neutrophils secrete MMP-8 which in turn facilitates neutrophils efflux through degrading the ECM in a feedback way. In the same meaning, gelatinase A and B (MMP-2 and MMP-9) interfere with recruited immune cells from peribroncho-vascular in alveolar space through modulating chemokines $[84,85]$. A recently made study showed that MMP-9 level was higher in first 3-5 days of infection. This elevation correlated negatively to the arterial partial pressure of oxygen/fraction of inspired oxygen ratio $(\mathrm{P} / \mathrm{F})$ which means sicker patients [86].

MMP-9 has been related to lung diseases through tissue remodeling like acute lung injuries asthma pulmonary fibrosis and pleural effusion. Released MMP-9 from inflammatory cells does promote alveolar capillary destruction leading to lung injury $[83,84,87]$. Also, Shi et al. suggested that MMP-3 serum level may be a valuable marker of COVID-19 by indicating a significant difference found between novel coronavirus pneumonia-infected patients and healthy people [88]. This particular MMP is widely expressed in human tissues since it is capable of cleaving several components of ECM components. Its main role is the ability to activate other pro-MMPs. During matrix turnover, MMP-3 or stromelysin-1 activates matrilysin, collagenases, gelatinase 
B and pro-MMP-1 to generate an active form of MMP-1. Its capacity of cleaving type I collagen makes it different from collagenase [13, 89].

Following the emerging cytokines flow after infection, tissue inhibitors of metalloproteinase (TIMPs) are secreted to maintain the matrix equilibrium and to regulate cytokines shedding, playing therefore a tremendous role after injury caused mainly by inflammation [90-93]. The TIMP-3 is a specific inhibitor of MMPs and ADAM family (metalloproteinase and disintegrin) and is expressed by several cell types via many tissues. This inhibitor is capable of inhibiting the very particular ADAM-17 [94-96], a metalloprotease and a disintegrin that cleave not only tumor necrosis factor alpha (pro-TNF-alpha) [97, 98], but also responsible of shedding the ACE2 receptor and seem to be implicated in the propagation and the aggravation of the infection. Binding SARS-CoV-2 to the ACE2 induces its shedding by ADAM-17, and its uptake by the virus in turn [14-16]. This shedding enhances probably several cellular signals including PKC activation [15] and is involved in virus uptake towards target cells [95]. The emergent hypothesis is that ACE2 down-regulation by ADAM-17 could be responsible for lung tissue damage and respiratory failure aggravation by the virus. It has been reported, in vivo and in vitro, that the inhibition of ADAM-17/TACE blocks ACE2 shedding and limits viral entry $[15,16]$. Its exact role in SARS-COV-2 invasion needs further investigations, indeed, while ADAM17 ability to cleave ACE2 is undisputable, it was demonstrated that only cleavage by TMPRSS2, and not by ADAM17 can promote virus entry into the cells in a SARS-CoV-1 model [95]. To more understand SARS-CoV-2 implication, we went through other possible pathways on viruses that belong to the same family. On an induced MHVA59-infected mice model (MHV is a mice hepatitis virus that belongs to the same family of Beta-coronaviruses, where SARS-CoV-2 is a considered member of this family) [17, 99-103], there was an upregulation in MMP-3, MMP-12 transcript levels. There was also an elevation in TIMP-1 circulating levels and mRNA [101]. This inhibitor is found to be correlated with viral virulence and suggests a probable implication in the antiviral response [101]. Since Beta-coronaviruses entry depends on cellular protease for a successful penetration in host cell, there is a probable downregulation of TIMP-2, TIMP-3 and TIMP-4 [92, 104, 105]. In fact, basic TIMP-1 levels are in first place low but are highly induced after triggered immune response on the contrary of TIMP-2, TIMP-3 and TIMP-4 that are constitutively secreted and modifications in their levels are lower than those of TIMP-1 in immune response [105-109]. The increase of MMP-3 [88] and MMP-9 [85] circulating levels during first days of infection on the optimum of the viral charge and a probable downregulation

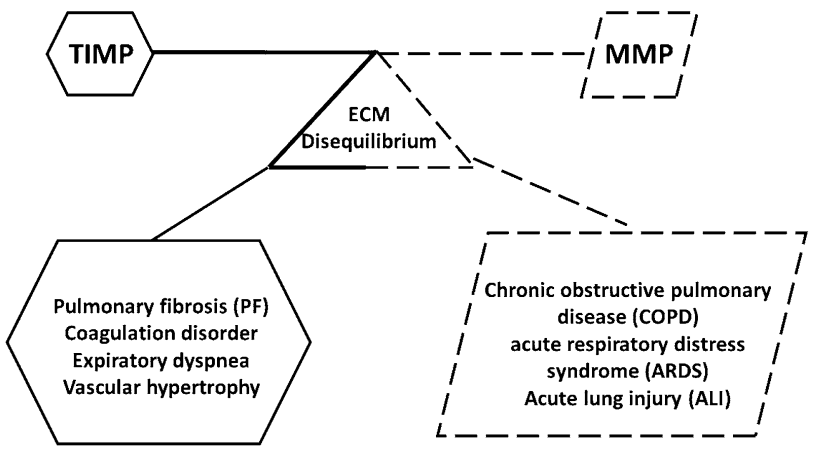

Fig. 3 Targeting ECM mediators as a therapeutic solution after SARS-CoV-2 infection could prevent from severe complications: matrix equilibrium is primordial for maintaining a healthy lung structure, when MMP/TIMP ration is in favor of MMPs, a matrix destruction occurs and when it is in favor of TIMPs a thickened matrix is observed. MMP matrix metalloproteinase, TIMP tissue inhibitor of matrix metalloproteinase, $E C M$ extracellular matrix

of their specific inhibitors could put the puzzle in this way: the virus turns all of the mediators in its favor by enhancing MMPs secretion during first days of infection that triggers a matrix disequilibrium. Their decrease in the upcoming period suggests an upregulation of their specific inhibitors to respond their sudden elevation. More precise experiments, subsequent measurements and longitudinal analyses could better explain this phenomenon.

\section{Are MMPs and their inhibitors probable therapeutic targets?}

An elevation in MMPs level implies a matrix disequilibrium that will probably modulate in turn their specific inhibitors (Fig. 3). These inhibitors are addressed towards MMPs to regulate their action. TIMPs used in lung injury mice models reduced the inflammatory state and ameliorated the injuries [109]. Induced inflammatory markers during the cytokine storm, enhance TIMPs secretion particularly TIMP-3 since it is mainly secreted by macrophages [110]. TIMP-3 is the highest ECM regulator because of its capacity to bind directly to the matrix [111]. Capable of shedding receptors and cleaving cytokines, this inhibitor has an anti-inflammatory effect that could restrain the explosive state of inflammatory markers after infection $[112,113]$. To increase TIMP-3 bioavailability, different approaches were conducted, like injecting recombinant TIMP-3 or through a mediated adenovirus gene [114, 115]. Therefore, TIMP-3 wide substrates and targets may imbalance some of the signaling pathways and mechanisms. These experiments are able to change radically the cell behavior by cleaving and shedding cell surface proteins including receptors, disintegrins and chemotactic elements. That is why a determined interval 
of its circulating level could offer a good prognostic marker since higher level implies also an ECM disequilibrium with several harmful consequences [110]. COVID-19 infections could induce an alveolar damage and enhance vascular permeability presumed in progressive hypoxemia, an ARDS or even an acute lung injury. As a consequence of immune cells activation and overexpression of cytokines, proteases, a probable acute lung injury (ALI) is established [116, 117]. ALI is characterized by a severe damage of alveolar barrier and mainly caused by an enhanced inflammatory response. Ventilated associated lung injury (VALI) has shown to be a common complication for COVID-19 patients and this can be only for worse [117]. To demonstrate MMPs implication in ALI and their probable potential effect in therapeutic experiments, animal models were established on clinical perturbations. On a deficient MMP-8 mice model and by treatment with an MMP-8 inhibitor, there was an improvement in gas exchange and a reduced damage after induced-ventilator lung injury [118]. However, Dolinay and his collaborators found that mice with an MMP- 8 deficiency developed a higher alveolar permeability after the mechanical ventilation than wild type mice [118]. In the same context, an induced lung injury by immune cells infiltration in MMP-9-deficient mice model showed a lower state of lung injury than wild type $[119,120]$. In fact, this gelatinase is probably implicated in decreasing pulmonary edema through healing the alveolar epithelium [121]. On the other hand, in response to a severe injury in lungs, fibrocytes and macrophages enhance collagen availability. The MMP-3 is considered to be the pro-generator of other MMPs since it is responsible for their activation. This stromelysin- 1 is implicated in reducing lung injury level in MMP-3-deficient mice through the reduction of the chemotactic activity. Chemotactic peptides generated by neutrophils were upregulated in MMP-3-deficient mice including macrophage inflammatory protein and the complement chemotactic (C5a) [122]. Furthermore, there has been evidence that MMP-12 known also as the macrophage elastase is able to regulate monocytes influx in lungs through generating elastin fragments that play the role of chemotactic elements for immune cells recruitment in a chronic lung injury and smoking model [122].

\section{SARS-CoV-2 new variant and matrix remodeling?}

Even though the emerging new variant of SARS-CoV-2, the SARS-CoV-2 VUI 20201201 (Variant Under Investigation, year 2020, month 12, variant 01) [123], is yet under investigation and by the limited existent data, we thought of elaborating this actuality from another perspective. This new variant has been identified via viral genomic sequencing and is characterized by several spike proteins mutation, namely deletion 144, deletion 69-70, N501Y, A570D, D614G, T716I, P681H, D1118H, S982A [124]. Preliminary investigations suggest that its probable increased transmissibility could reach the $70 \%$. Among these mutations, the N501Y is capable of increasing the ACE2 affinity since it touches the contact residues of the receptor-binding domain and seems to be highly related to virulence and infectivity factors in mice models [125, 126]. As for the $\mathrm{P} 681 \mathrm{H}$ mutation, it creates a new furin cleavage site among the $\mathrm{S} 1$ and $\mathrm{S} 2$ and this site appears to be absent in other coronaviruses. This genetic variation is probably capable of promoting the viral entry in epithelial respiratory cells $[17,127,128]$. As for the $69-70$ spike deletion, it has been shown to be associated to multiple RBD mutations [128, 129]. In summary, these mutations do enhance viral infiltration in host cells which explains its high transmissibility but do not alter the infection severity until the recent findings [130]. Based on these limited data, we can suggest that matrix remodeling after SARSCoV-2 and SARS-CoV-2 VUI 20201201 will take the same road. Both of them will engender matrix destruction in a first way after activating the first line of defense which is presumed in an innate response. Afterwards, the real worry could be in activating more matrix mediators that will probably increase their secretion in a sudden way and set off several complications. It remains for us to investigate their evolution in the periods to come since there are still not enough data for this cluster.

\section{Conclusion}

Matrix remodeling has been widely implicated in several physiological, pathological and homeostasis state. Its mediators are capable of changing the fate of an organ since they are present and implicated in cell-cell and in a circulating way. Coronavirus invasion in the human body did alter matrix equilibrium. After elucidating matrix remodeling from this point of view, it is clearer that these mechanisms are pathologically modified during SARS$\mathrm{CoV}-2$ emerging. Since the lack of data, it will be interesting to focus on MMPs and their inhibitors for a therapeutic journey and to consider them as probable targets for a long-term treatment as cured patients remain with sequels.

Acknowledgements Illustrated figures were technically performed by Nesrine Fourti, a Phd student in our Biochemistry Department and Research Laboratory in la Rabta Hospital University in Tunis. We also thank Pr Alexandre Mebazaa from the INSERM UMRS 942, Department of Anesthesia and Critical Care in the Lariboisière Hospital, APHP, Paris, France (University Paris Diderot, Sorbonne Paris), France and Dr Charles de Roquetaillade from the Reanimation department in 
the Andre Mignot Hospital in France for their effort in revising and correcting the manuscript.

\section{Declarations}

Conflict of interest The authors declare that they have no conflict of interest and no financial support regarding this review project.

\section{References}

1. Zhou P, Yang XL, Wang XG, Hu B, Zhang L, Zhang W, Si HR, Zhu Y, Li B, Huang CL, Chen HD, Chen J, Luo Y, Guo H, Jiang RD, Liu MQ, Chen Y, Shen XR, Wang X, Zheng XS, Zhao K, Chen QJ, Deng F, Liu LL, Yan B, Zhan FX, Wang YY, Xiao GF, Shi ZL. A pneumonia outbreak associated with a new coronavirus of probable bat origin. Nature. 2020;579:270-3.

2. Wu F, Zhao S, Yu B, Chen YM, Wang W, Song ZG, Hu Y, Tao ZW, Tian JH, Pei YY, Yuan ML, Zhang YL, Dai FH, Liu Y, Wang QM, Zheng JJ, Xu L, Holmes EC, Zhang YZ. A new coronavirus associated with human respiratory disease in China. Nature. 2020;579:265-9.

3. Lu R, Zhao X, Li J, Niu P, Yang B, Wu H, Wang W, Song H, Huang B, Zhu N, Bi Y, Ma X, Zhan F, Wang L, Hu T, Zhou H, Hu Z, Zhou W, Zhao L, Chen J, Meng Y, Wang J, Lin Y, Yuan J, Xie Z, Ma J, Liu WJ, Wang D, Xu W, Holmes EC, Gao GF, Wu G, Chen W, Shi W, Tan W. Genomic characterisation and epidemiology of 2019 novel coronavirus: implications for virus origins and receptor binding. Lancet. 2020;395:565-74.

4. Hoffmann M, Kleine-Weber H, Schroeder S, Krüger N, Herrler T, Erichsen S, Schiergens TS, Herrler G, Wu NH, Nitsche A, Müller MA, Drosten C, Pöhlmann S. SARS- CoV-2 cell entry depends on ACE2 and TMPRSS2 and is blocked by a clinically proven protease inhibitor. Cell. 2020;181:271-80.

5. Andersen KG, Rambaut A, Lipkin WI, Holmes EC, Garry RF. The proximal origin of SARS-CoV-2. Nat Med. 2020;26:450-2.

6. Du L, He Y, Zhou Y, Liu S, Zheng BJ, Jiang S. The spike protein of SARS- CoV - a target for vaccine and therapeutic development. Nat Rev Microbiol. 2009;7:226-36.

7. Cui J, Li F, Shi ZL. Origin and evolution of pathogenic coronaviruses. Nat Rev Microbiol. 2019;17:181-92.

8. Tay MZ, Poh CM, Rénia L, MacAry PA, Ng LF. The trinity of COVID-19: immunity, inflammation and intervention. Nat Rev Immunol. 2020;20:363-74.

9. Mehta P, McAuley DF, Brown M, Sanchez E, Tattersall RS, Manson JJ, HLH Across Speciality Collaboration, UK. COVID19: consider cytokine storm syndromes and immunosuppression. Lancet. 2020;395:1033-4.

10. Ohbayashi H. Matrix metalloproteinases in lung diseases. Curr Protein Pept Sci. 2002;3:409-21.

11. Overall CM. Molecular determinants of metalloproteinase substrate specificity: matrix metalloproteinase substrate binding domains, modules, and exosites. Mol Biotechnol. 2002;22:51-86.

12. Sbardella D, Fasciglione GF, Gioia M, Ciaccio C, Tundo GR, Marini S, Coletta M. Human matrix metalloproteinases: an ubiquitarian class of enzymes involved in several pathological processes. Mol Asp Med. 2012;33:119-208.

13. Nagase H, Visse R, Murphy G. Structure and function of matrix metalloproteinases and TIMPs. Cardiovasc Res. 2006;69:562-73.

14. Palau V, Riera M, Soler MJ. ADAM17 inhibition may exert a protective effect on COVID-19. Nephrol Dial Transplant. 2020;35:1071-2.

15. Haga S, Yamamoto N, Nakai-Murakami C, Osawa Y, Tokunaga K, Sata T, Yamamoto N, Sasazuki T, Ishizaka Y. Modulation of
TNF-alpha-converting enzyme by the spike protein of SARS$\mathrm{CoV}$ and ACE2 induces TNF-alpha production and facilitates viral entry. Proc Natl Acad Sci USA. 2008;105:7809-14.

16. Haga S, Nagata N, Okamura T, Yamamoto N, Sata T, Yamamoto N, Sasazuki T, Ishizaka Y. TACE antagonists blocking ACE2 shedding caused by the spike protein of SARS-CoV are candidate antiviral compounds. Antiviral Res. 2010;85:551-5.

17. Hoffmann M, Kleine-Weber H, Pöhlmann S. A multibasic cleavage site in the spike protein of SARS-CoV-2 is essential for infection of human lung cells. Mol Cell. 2020;78:779-784.e5.

18. Uhal BD, Dang M, Dang V, Llatos R, Cano E, Abdul-Hafez A, Markey J, Piasecki CC, Molina-Molina M. Cell cycle dependence of ACE-2 explains downregulation in idiopathic pulmonary fibrosis. Eur Respir J. 2013;42(1):198-210.

19. Walls AC, Park YJ, Tortorici MA, Wall A, McGuire AT, Veesler D. Structure, function, and antigenicity of the SARSCoV-2 spike glycoprotein. Cell. 2020;181:281-292.e6.

20. Yesudhas D, Srivastava A, Gromiha MM. COVID 19 outbreak: history, mechanism, transmission, structural studies and therapeutics. Infection. 2020;4:1-15.

21. Millet JK, Whittaker GR. Host cell proteases: critical determinants of coronavirus tropism and pathogenesis. Virus Res. 2015;202:120-34.

22. Gui M, Song W, Zhou H, Xu J, Chen S, Xiang Y, Wang X. Cryo-electron microscopy structures of the SARS-CoV spike glycoprotein reveal a prerequisite conformational state for receptor binding. Cell Res. 2017;27:119-29.

23. Shang J, Wan Y, Luo C, Ye G, Geng Q, Auerbach A, Li F. Cell entry mechanisms of SARS-CoV-2. Proc Natl Acad Sci USA. 2020;117:11727-34.

24. Coutard B, Valle C, de Lamballerie X, Canard B, Seidah NG, Decroly E. The spike glycoprotein of the new coronavirus 2019-nCoV contains a furin-like cleavage site absent in $\mathrm{CoV}$ of the same clade. Antiviral Res. 2020;176:104742.

25. Kam YW, Okumura Y, Kido H, Ng LF, Bruzzone R, Altmeyer R. Cleavage of the SARS coronavirus spike glycoprotein by airway proteases enhances virus entry into human bronchial epithelial cells in vitro. PLoS One. 2009;4:e7870.

26. Kuba K, Imai Y, Ohto-Nakanishi T, Penninger J. Trilogy of ACE2: a peptidase in the renin-angiotensin system, a SARS receptor, and a partner for amino acid transporters. Pharmacol Ther. 2010;128:119-28.

27. Donoghue M, Hsieh F, Baronas E, Godbout K, Gosselin M, Stagliano N, Donovan M, Woolf B, Robison K, Jeyaseelan $\mathrm{R}$, Breitbart RE, Acton S. A novel angiotensin-converting enzyme-related carboxypeptidase (ACE2) converts angiotensin I to angiotensin 1-9. Circ Res. 2000;87:E1-9.

28. Santos RAS, Sampaio WO, Alzamora AC, Motta-Santos D, Alenina N, Bader M, Campagnole-Santos MJ. The ACE2/ angiotensin-(1-7)/MAS axis of the renin-angiotensin system: focus on angiotensin-(1-7). Physiol Rev. 2018;98:505-53.

29. Keidar S, Kaplan M, Gamliel-Lazarovich A. ACE2 of the heart: from angiotensin I to angiotensin (1-7). Cardiovasc Res. 2007;73:463-9.

30. Horiuchi M, Akishita M, Dzau V. Recent progress in angiotensin II type 2 receptor research in the cardiovascular system. Hypertension. 1999;33:613-21.

31. Vaduganathan M, Vardeny O, Michel T, McMurray JJ, Pfeffer MA, Solomon SD, et al. Renin-angiotensin-aldosterone system inhibitors in patients with Covid-19. N Engl J Med. 2020;382:1653-9.

32. Tipnis SR, Hooper NM, Hyde R, Karran E, Christie G, Turner AJ. A human homologue of angiotensin-converting enzyme. J Biol Chem. 2000;275:33238-43.

33. Alexandre J, Cracowski JL, Richard V, Bouhanick B, 'Drugs, COVID-19' working group of the French Society 
of Pharmacology, Therapeutics. Renin-angiotensin-aldosterone system and COVID-19 infection. Ann Endocrinol. 2020;81:63-7.

34. Kuhn JH, Li W, Choe H, Farzan M. Angiotensin-converting enzyme 2: a functional receptor for SARS coronavirus. Cell Mol Life Sci. 2004;61(21):2738-43.

35. Liu F, Mih JD, Shea BS, Kho AT, Sharif AS, Tager AM, Tschumperlin DJ. Feedback amplification of fibrosis through matrix stiffening and COX-2 suppression. J Cell Biol. 2010;190:693-706.

36. Liu Y, Yang Y, Zhang C, Huang F, Wang F, Yuan J, Wang Z, Li J, Li J, Feng C, Zhang Z, Wang L, Peng L, Chen L, Qin Y, Zhao D, Tan S, Yin L, Xu J, Zhou C, Jiang C, Liu L. Clinical and biochemical indexes from 2019-nCoV infected patients linked to viral loads and lung injury. Sci China Life Sci. 2020;63(3):364-74.

37. Hamming I, Timens W, Bulthuis MLC, Lely AT, Navis GJ, van Goor H. Tissue distribution of ACE2 protein, the functional receptor for SARS coronavirus. A first step in understanding SARS pathogenesis. J Pathol. 2004;203:631-7.

38. Zou X, Chen K, Zou J, Han P, Hao J, Han Z. Single-cell RNAseq data analysis on the receptor ACE2 expression reveals the potential risk of different human organs vulnerable to Wuhan 2019-nCoV infection. Front Med. 2020;14:185-92.

39. Zhang H, Li HB, Lyu JR, Lei XM, Li W, Wu G, Lyu J, Dai ZM. Specific ACE2 expression in small intestinal enterocytes may cause gastrointestinal symptoms and injury after 2019-nCoV infection. Int J Infect Dis. 2020;96:19-24.

40. Hsieh WY, Kuan TC, Cheng KS, Liao YC, Chen MY, Lin PH, Hsu YC, Huang CY, Hsu WH, Yu SY, Lin CS. ACE/ACE2 ratio and MMP-9 activity as potential biomarkers in tuberculous pleural effusions. Int J Biol Sci. 2012;8:1197-205.

41. Empey DW. Diseases of the respiratory system. Introduction: structure and function of the lungs. Br Med J. 1978;1:631-3.

42. Murray JF. The structure and function of the lung. Int J Tuberc Lung Dis. 2010;14:391-6.

43. Matthay MA, Zimmerman GA. Acute lung injury and the acute respiratory distress syndrome: four decades of inquiry into pathogenesis and rational management. Am J Respir Cell Mol Biol. 2005;33:319-27.

44. Matthay MA, Zemans RL. The acute respiratory distress syndrome: pathogenesis and treatment. Annu Rev Pathol. 2011;6:147-63.

45. Matthes SA, Hadley R, Roman J, White E. Comparative biology of the normal lung extracellular matrix. In: Parent RA, editor. Comparative biology of the normal lung. 2nd ed. Amsterdam: Elsevier AP; 2015. p. 387-402.

46. Dunsmore SE, Rannels DE. Extracellular matrix biology in the lung. Am J Physiol. 1996;270:L3-27.

47. Sicari BM, Zhang L, Londono R, Badylak SF. An assay to quantify chemotactic properties of degradation products from extracellular matrix. Methods Mol Biol. 2014;1202:103-10.

48. Bottaro DP, Liebmann-Vinson A, Heidaran MA. Molecular signaling in bioengineered tissue microenvironments. Ann N Y Acad Sci. 2002;961:143-53

49. Suki B, Stamenovic D, Hubmayr R. Lung parenchymal mechanics. Compr Physiol. 2011;1:1317-51.

50. Bornstein P, Sage EH. Matricellular proteins: extracellular modulators of cell function. Curr Opin Cell Biol. 2002;14:608-16.

51. Channappanavar R, Fehr AR, Vijay R, Mack M, Zhao J, Meyerholz DK, Perlman S. Dysregulated type I interferon and inflammatory monocyte-macrophage ressponses cause lethal pneumonia in SARS-CoV-infected mice. Cell Host Microbe. 2016;19:181-93.
52. Siddiqi HK, Mehra MR. COVID-19 illness in native and immunosuppressed states: a clinical-therapeutic staging proposal. J Heart Lung Transplant. 2020;39(5):405-7.

53. Bonny V, Maillard A, Mousseaux C, Plaçais L, Richier Q. COVID-19: physiopathologie d'une maladie à plusieurs visages [COVID-19: pathogenesis of a multi-faceted disease]. Rev Med Interne. 2020;41(6):375-89.

54. Channappanavar R, Fehr AR, Zheng J, Wohlford-Lenane C, Abrahante JE, Mack M, Sompallae R, McCray PB Jr, Meyerholz DK, Perlman S. IFN-I response timing relative to virus replication determines MERS coronavirus infection outcomes. J Clin Investig. 2019;129(9):3625-39.

55. McGonagle D, Sharif K, O'Regan A, Bridgewood C. The role of cytokines including interleukin-6 in COVID-19 induced pneumonia and macrophage activation syndrome-like disease. Autoimmun Rev. 2020;19(6):102537.

56. Ye Q, Wang B, Mao J. The pathogenesis and treatment of the 'Cytokine Storm' in COVID-19. J Infect. 2020;80(6):607-13.

57. Behrens EM, Koretzky GA. Review: cytokine storm syndrome: looking toward the precision medicine era. Arthritis Rheumatol. 2017;69(6):1135-43.

58. Kheradmand F, Shan M, Xu C, Corry DB. Autoimmunity in chronic obstructive pulmonary disease: clinical and experimental evidence. Expert Rev Clin Immunol. 2012;8:285-92.

59. Cosio MG, Saetta M, Agusti A. Immunologic aspects of chronic obstructive pulmonary disease. N Engl J Med. 2009;360:2445-54.

60. Midwood K, Sacre S, Piccinini AM, Inglis J, Trebaul A, Chan E, Drexler S, Sofat N, Kashiwagi M, Orend G, Brennan F, Foxwell B. Tenascin-C is an endogenous activator of Toll-like receptor 4 that is essential for maintaining inflammation in arthritic joint disease. Nat Med. 2009;15:774-80.

61. Schaefer L, Babelova A, Kiss E, Hausser HJ, Baliova M, Krzyzankova M, Marsche G, Young MF, Mihalik D, Gotte M, Malle E, Schaefer RM, Grone HJ. The matrix component biglycan is proinflammatory and signals through Toll-like receptors 4 and 2 in macrophages. J Clin Investig. 2005;115:2223-33.

62. Piccinini AM, Midwood KS. DAMPening inflammation by modulating TLR signaling. Mediat Inflamm. 2010;2010:672395.

63. Friedman SL, Sheppard D, Duffield JS, Violette S. Therapy for fibrotic diseases: nearing the starting line. Sci Transl Med. 2013;5(167):167sr1.

64. Pfister RR, Haddox JL, Lam KW, Lank KM. Preliminary characterization of a polymorphonuclear leukocyte stimulant isolated from alkali-treated collagen. Investig Ophthalmol Vis Sci. 1988;29:955-62.

65. Zheng MH, Chen J, Kirilak Y, Willers C, Xu J, Wood D. Porcine small intestine submucosa (SIS) is not an acellular collagenous matrix and contains porcine DNA: possible implications in human implantation. J Biomed Mater Res B Appl Biomater. 2005;73:61-7.

66. Leng L, Cao R, Ma J, Mou D, Zhu Y, Li W, Lv L, Gao D, Zhang S, Gong F, Zhao L, Qiu B, Xiang H, Hu Z, Feng Y, Dai Y, Zhao J, Wu Z, Li H, Zhong W. Pathological features of COVID19-associated lung injury: a preliminary proteomics report based on clinical samples. Signal Transduct Target Ther. 2020;5:240.

67. Anzueto A. Exogenous surfactant in acute respiratory distress syndrome: more is better. Eur Respir J. 2002;19(5):787-9.

68. Piva S, DiBlasi RM, Slee AE, Jobe AH, Roccaro AM, Filippini M, Latronico N, Bertoni M, Marshall JC, Portman MA. Surfactant therapy for COVID-19 related ARDS: a retrospective case-control pilot study. Respir Res. 2021;22(1):20.

69. Parker MW, Rossi D, Peterson M, Smith K, Sikstrom K, White ES, Connett JE, Henke CA, Larsson O, Bitterman PB. Fibrotic 
extracellular matrix activates a profibrotic positive feedback loop. J Clin Investig. 2014;124:1622-35.

70. Laronha H, Caldeira J. Structure and function of human matrix metalloproteinases. Cells. 2020;9:1076.

71. Cui N, Hu M, Khalil RA. Biochemical and biological attributes of matrix metalloproteinases. Prog Mol Biol Transl Sci. 2017; 147:1-73.

72. Nelson AR, Fingleton B, Rothenberg ML, Matrisian LM. Matrix metalloproteinases: biologic activity and clinical implications. J Clin Oncol. 2000;18:1135-49.

73. Bode W, Gomis-Rüth FX, Stöckler W. Astacins, serralysins, snake venom and matrix metalloproteinases exhibit identical zinc-binding environments (HEXXHXXGXXH and Met-turn) and topologies and should be grouped into a common family, the 'metzincins.' FEBS Lett. 1993;331:134-40.

74. Hoekstra R, Eskens FA, Verweij J. Matrix metalloproteinase inhibitors: current developments and future perspectives. Oncologist. 2001;6:415-27.

75. Jacobsen JA, Major Jourden JL, Miller MT, Cohen SM. To bind zinc or not to bind zinc: an examination of innovative approaches to improved metalloproteinase inhibition. Biochim Biophys Acta. 2010;1803:72-94.

76. Li Q, Park PW, Wilson CL, Parks WC. Matrilysin shedding of syndecan-1 regulates chemokine mobilization and transepithelial efflux of neutrophils in acute lung injury. Cell. 2002;111:635-46.

77. Parks WC, Wilson CL, Lopez-Boado YS. Matrix metalloproteinases as modulators of inflammation and innate immunity. Nat Rev Immunol. 2004;4:617-29.

78. Korpos E, Wu C, Sorokin L. Multiple roles of the extracellular matrix in inflammation. Curr Pharm Des. 2009;15:1349-57.

79. van Goor H, Melenhorst WBWH, Turner AJ, Holgate ST. Adamalysins in biology and disease. J Pathol. 2009;219:277-86.

80. Seals DF, Courtneidge SA. The ADAMs family of metalloproteases: multidomain proteins with multiple functions. Genes Dev. 2003;17:7-30.

81. White JM, Bridges L, DeSimone D, Tomczuk M, Wolfsberg T. Introduction to the ADAM family. In: Hooper NM, Lendeckel $\mathrm{U}$, editors. The ADAM family of proteases: proteases in biology and disease. Dordrecht: Springer; 2005. p. 1-28.

82. Manicone AM, Birkland TP, Lin M, Betsuyaku T, van Rooijen N, Lohi J, Keski-Oja J, Wang Y, Skerrett SJ, Parks WC. Epilysin (MMP-28) restrains early macrophage recruitment in Pseudomonas aeruginosa pneumonia. J Immunol. 2009;182:3866-76.

83. Corry DB, Rishi K, Kanellis J, Kiss A, Song Lz LZ, Xu J, Feng L, Werb Z, Kheradmand F. Decreased allergic lung inflammatory cell egression and increased susceptibility to asphyxiation in MMP2- deficiency. Nat Immunol. 2002;3:347-53.

84. Corry DB, Kiss A, Song LZ, Song L, Xu J, Lee SH, Werb Z, Kheradmand F. Overlapping and independent contributions of MMP2 and MMP9 to lung allergic inflammatory cell egression through decreased CC chemokines. FASEB J. 2004;18:995-7.

85. Ueland T, Holter JC, Holten AR, Müller KE, Lind A, Bekken GK, Dudman S, Aukrust P, Dyrhol-Riise AM, Heggelund L. Distinct and early increase in circulating MMP-9 in COVID-19 patients with respiratory failure. J Infect. 2020;81:e41-3.

86. Atkinson JJ, Senior RM. Matrix metalloproteinase-9 in lung remodeling. Am J Respir Cell Mol Biol. 2003;28:12-24.

87. Davey A, McAuley DF, O'Kane CM. Matrix metalloproteinases in acute lung injury: mediators of injury and drivers of repair. Eur Respir J. 2011;38:959-70.

88. Shi S, Su M, Shen G, Hu Y, Yi F, Zeng Z, Zhu P, Yang G, Zhou $\mathrm{H}$, Li Q, Xie X. Matrix metalloproteinase 3 as a valuable marker for patients with COVID-19. J Med Virol. 2021; 93(1):528-32.
89. Shapiro SD. Matrix metalloproteinase degradation of extracellular matrix: biological consequences. Curr Opin Cell Biol. 1998;10:602-8.

90. Baker AH, Edwards DR, Murphy G. Metalloproteinase inhibitors: biological actions and therapeutic opportunities. J Cell Sci. 2002;115:3719-27.

91. Brew K, Dinakarpandian D, Nagase H. Tissue inhibitors of metalloproteinases: evolution, structure and function. Biochim Biophys Acta. 2000;1477:267-83.

92. Wei S, Kashiwagi M, Kota S, Xie Z, Nagase H, Brew K. Reactive site mutations in tissue inhibitor of metalloproteinase-3 disrupt inhibition of matrix metalloproteinases but not tumor necrosis factor-alpha-converting enzyme. J Biol Chem. 2005;280:32877-82.

93. Illman SA, Keski-Oja J, Lohi J. Promoter characterization of the human and mouse epilysin (MMP-28) genes. Gene. 2001;275:185-94.

94. Li QL, Illman SA, Wang HM, Liu DL, Lohi J, Zhu C. Matrix metalloproteinase-28 transcript and protein are expressed in rhesus monkey placenta during early pregnancy. Mol Hum Reprod. 2003;9:205-11.

95. Illman SA, Keski-Oja J, Parks WC, Lohi J. The mouse matrix metalloproteinase, epilysin (MMP-28), is alternatively spliced and processed by a furin-like proprotein convertase. Biochem J. 2003;375:191-7.

96. Black RA, Rauch CT, Kozlosky CJ, Peschon JJ, Slack JL, Wolfson MF, Castner BJ, Stocking KL, Reddy P, Srinivasan S, Nelson N, Boiani N, Schooley KA, Gerhart M, Davis R, Fitzner JN, Johnson RS, Paxton RJ, March CJ, Cerretti DP. A metalloproteinase disintegrin that releases tumour-necrosis factor-alpha from cells. Nature. 1997;385:729-33.

97. Lambert DW, Yarski M, Warner FJ, Thornhill P, Parkin ET, Smith AI, Hooper NM, Turner AJ. Tumor necrosis factor-a convertase (ADAM17) mediates regulated ectodomain shedding of the severe-acute respiratory syndrome-coronavirus (SARS$\mathrm{CoV}$ ) receptor, angiotensin-converting enzyme-2 (ACE2). J Biol Chem. 2005;280:30113-9.

98. Heurich A, Hofmann-Winkler H, Gierer S, Liepold T, Jahn O, Pohlmann S. TMPRSS2 and ADAM17 cleave ACE2 differentially and only proteolysis by TMPRSS2 augments entry driven by the severe acute respiratory syndrome coronavirus spike protein. J Virol. 2014;88:1293-307.

99. Wang Q, Haluskey JA, Lavi E. Coronavirus MHV-A59 causes upregulation of interferon-beta RNA in primary glial cell cultures. Adv Exp Med Biol. 1998;440:451-4.

100. Zhou J, Stohlman SA, Atkinson R, Hinton DR, Marten NW. Matrix metalloproteinase expression correlates with virulence following neurotropic mouse hepatitis virus infection. J Virol. 2002;76:7374-84.

101. Li F. Structure, function, and evolution of coronavirus spike proteins. Annu Rev Virol. 2016;3:237-61.

102. Lavi E, Gilden DH, Wroblewska Z, Rorke LB, Weiss SR. Experimental demyelination produced by the A59 strain of mouse hepatitis virus. Neurology. 1984;34:597-603.

103. Bond M, Fabunmi RP, Baker AH, Newby AC. Synergistic upregulation of metalloproteinase- 9 by growth factors and inflammatory cytokines: an absolute requirement for transcription factor NF-kappa B. FEBS Lett. 1998;435:29-34.

104. Marten NW, Zhou J. The role of metalloproteinases in corona virus infection. In: Lavi E, Constantinescu CS, editors. Experimental models of multiple sclerosis. Boston: Springer; 2005. p. 839-48.

105. Leco KJ, Hayden LJ, Sharma RR, Rocheleau H, Greenberg AH, Edwards DR. Differential regulation of TIMP-1 and TIMP-2 mRNA expression in normal and Ha-ras-transformed murine fibroblasts. Gene. 1992;117:209-17. 
106. Madtes DK, Elston AL, Kaback LA, Clark JG. Selective induction of tissue inhibitor of metalloproteinase-1 in bleomycininduced pulmonary fibrosis. Am J Respir Cell Mol Biol. 2001;24:599-607.

107. Pagenstecher A, Stalder AK, Kincaid CL, Shapiro SD, Campbell IL. Differential expression of matrix metalloproteinase and tissue inhibitor of matrix metalloproteinase genes in the mouse central nervous system in normal and inflammatory states. Am J Pathol. 1998;152:729-41.

108. Gipson TS, Bless NM, Shanley TP, Crouch LD, Bleavins MR, Younkin EM, Sarma V, Gibbs DF, Tefera W, McConnell PC, Mueller WT, Johnson KJ, Ward PA. Regulatory effects of endogenous protease inhibitors in acute lung inflammatory injury. $\mathbf{J}$ Immunol. 1999;162:3653-62.

109. Mohammed FF, Smookler DS, Taylor SE, Fingleton B, Kassiri Z, Sanchez OH, English JL, Matrisian LM, Au B, Yeh WC, Khokha R. Abnormal TNF activity in Timp3-/- mice leads to chronic hepatic inflammation and failure of liver regeneration. Nat Genet. 2004;36:969-77.

110. Mohammed FF, Smookler DS, Khokha R. Metalloproteinases, inflammation, and rheumatoid arthritis. Ann Rheum Dis. 2003;62(Suppl. 2):ii43-7.

111. Smookler DS, Mohammed FF, Kassiri Z, Duncan GS, Mak TW, Khokha R. Tissue inhibitor of metalloproteinase 3 regulates TNF-dependent systemic inflammation. J Immunol. 2006;176:721-5.

112. Black RA. TIMP3 checks inflammation. Nat Genet. 2004;36:934-5.

113. Black RA, Castner B, Slack J, Tocker J, Eisenman J, Jacobson E, Delaney J, Winters D, Hecht R, Bendele A. A14 injected TIMP-3 protects cartilage in a rat meniscal tear model. Osteoarthr Cartil. 2006;14:S23-4. https://doi.org/10.1016/S1063-4584(07) 60467-1.

114. Ahonen M, Baker AH, Kähäri VM. Adenovirus-mediated gene delivery of tissue inhibitor of metalloproteinases-3 inhibits invasion and induces apoptosis in melanoma cells. Cancer Res. 1998;58:2310-5.

115. Li L, Huang Q, Wang DC, Ingbar DH, Wang X. Acute lung injury in patients with COVID-19 infection. Clin Transl Med. 2020;1:20-7.

116. Gupta VK, Alkandari BM, Mohammed W, Tobar AM, Abdelmohsen MA. Ventilator associated lung injury in severe COVID19 pneumonia patients - case reports: ventilator associated lung injury in COVID-19. Eur J Radiol Open. 2020;8:100310.

117. Albaiceta GM, Gutierrez-Fernández A, García-Prieto E, Puente XS, Parra D, Astudillo A, Campestre C, Cabrera S, GonzalezLopez A, Fueyo A, Taboada F, López-Otin C. Absence or inhibition of matrix metalloproteinase- 8 decreases ventilator-induced lung injury. Am J Respir Cell Mol Biol. 2010;43:555-63.

118. Dolinay T, Wu W, Kaminski N, Ifedigbo E, Kaynar AM, Szilasi M, Watkins SC, Ryter SW, Hoetzel A, Choi AM. Mitogen-activated protein kinases regulate susceptibility to ventilator-induced lung injury. PLoS ONE. 2008;3(2):e1601.

119. Warner RL, Beltran L, Younkin EM, Lewis CS, Weiss SJ, Varani J, Johnson KJ. Role of stromelysin 1 and gelatinase B in experimental acute lung injury. Am J Respir Cell Mol Biol. 2001;24:537-44.

120. O'Kane CM, McKeown SW, Perkins GD, Bassford CR, Gao F, Thickett DR, McAuley DF. Salbutamol up-regulates matrix metalloproteinase- 9 in the alveolar space in the acute respiratory distress syndrome. Crit Care Med. 2009;37:2242-9.

121. Wang M, Qin X, Mudgett JS, Ferguson TA, Senior RM, Welgus HG. Matrix metalloproteinase deficiencies affect contact hypersensitivity: Stromelysin 1 deficiency prevents the response and gelatinase B deficiency prolongs the response. Proc Natl Acad Sci USA. 1999;96:6885-9.
122. Hautamaki RD, Kobayashi DK, Senior RM, Shapiro SD. Requirement for macrophage elastase from cigarette smokeinduced emphysema in mice. Science. 1997;277:2002-4.

123. Rambaut A, Loman N, Pybus O, Barclay W, Barrett J, Carabelli A, Connor T, Peacock T, Robertson DL, Volz E, Rambaut A, Loman N, Pybus O, et al. (CoG-UK). Preliminary genomic characterisation of an emergent SARS-CoV-2 lineage in the UK defined by a novel set of spike mutations. Dec 18, 2020. https:// virological.org/t/preliminary-genomic-characterisation-of-anemergent-sars-cov-2-lineage-in-the-uk-defined-by-a-novel-setof-spike-mutations/563. Accessed 31 Jan 2021.

124. Gu H, Chen Q, Yang G, He L, Fan H, Deng YQ, Wang Y, Teng Y, Zhao Z, Cui Y, Li Y, Li XF, Li J, Zhang NN, Yang X, Chen S, Guo Y, Zhao G, Wang X, Luo DY, Wang H, Yang X, Li Y, Han G, He Y, Zhou X, Geng S, Sheng X, Jiang S, Sun S, Qin CF, Zhou Y. Adaptation of SARS-CoV-2 in BALB/c mice for testing vaccine efficacy. Science. 2020;369(6511):1603-7.

125. Starr TN, Greaney AJ, Hilton SK, Ellis D, Crawford KHD, Dingens AS, Navarro MJ, Bowen JE, Tortorici MA, Walls AC, King NP, Veesler D, Bloom JD. Deep mutational scanning of SARSCoV-2 receptor binding domain reveals constraints on folding and ACE2 binding. Cell. 2020;182(5):1295-1310.e20.

126. Peacock TP, Goldhill DH, Zhou J, Baillon L, Frise R, Swann OC, Kugathasan R, Penn R, Brown JC, Sanchez-David RY, Braga L, Williamson MK, Hassard JA, Staller E, Hanley B, Osborn M, Giacca M, Davidson AD, Matthews DA, Barclay WS. The furin cleavage site of SARS-CoV-2 spike protein is a key determinant for transmission due to enhanced replication in airway cells. Cold Spring Harb Lab. 2020. https://doi.org/10.1101/2020.09. 30.318311.

127. Zhu Y, Feng F, Gaowei Hu, Wang Y, Yin Yu, Zhu Y, Wei Xu, et al. The S1/S2 boundary of SARS-CoV-2 spike protein modulates cell entry pathways and transmission. Cold Spring Harb Lab. 2020. https://doi.org/10.1101/2020.08.25.266775.

128. McCarthy KR, Rennick LJ, Nambulli S, Robinson-McCarthy LR, Bain WG, Haidar G, Duprex WP. Natural deletions in the SARS-CoV-2 spike glycoprotein drive antibody escape. Microbiol bioRxiv. 2020. https://doi.org/10.1101/2020.11.19.389916.

129. Kemp SA, Collier DA, Datir R, Gayed S, Jahun A, Hosmillo M, Ferreira IATM, Rees-Spear C, Mlcochova P, Lumb IU, Roberts D, Chandra A, Temperton N, The CITIID-NIHR BioResource COVID-19 Collaboration, The COVID-19 Genomics UK (COGUK) Consortium, Sharrocks K, Blane E, Briggs JAG, van Gils MJ, Smith KGC, Bradley JR, Smith C, Goldstein RA, Goodfellow IG, Smielewska A, Skittrall JP, Gouliouris T, GkraniaKlotsas E, Illingworth CJR, McCoy LE, Gupta RK. Neutralising antibodies drive spike mediated SARS-CoV-2 evasion. Infectious diseases (except HIV/AIDS). MedRxiv. 2020. https://doi.org/10. 1101/2020.12.05.20241927.

130. Young BE, Fong SW, Chan YH, Mak TM, Ang LW, Anderson DE, Lee CY, Amrun SN, Lee B, Goh YS, Su YCF, Wei WE, Kalimuddin S, Chai LYA, Pada S, Tan SY, Sun L, Parthasarathy P, Chen YYC, Barkham T, Lin RTP, Maurer-Stroh S, Leo YS, Wang LF, Renia L, Lee VJ, Smith GJD, Lye DC, Ng LFP. Effects of a major deletion in the SARSCoV-2 genome on the severity of infection and the inflammatory response: an observational cohort study. Lancet. 2020;396:603-11.

Publisher's Note Springer Nature remains neutral with regard to jurisdictional claims in published maps and institutional affiliations. 